\title{
THE PRELIMINARY ADSORPTION INVESTIGATION OF URTICA DIOICA L. BIOMASS MATERIAL AS A POTENTIAL BIOSORBENT FOR HEAVY METAL IONS
}

\author{
VLADIMIR D. DIMITRIJEVIĆa, MAJA N. STANKOVIĆa, \\ DRAGAN M. ĐORĐEVIĆa ${ }^{*}$, IVAN M. KRSTIĆ ${ }^{b}$, MILICA G. NIKOLIĆa, \\ ALEKSANDAR L.J. BOJIĆa AND NENAD S. KRSTIĆa
}

\begin{abstract}
The removal of $\mathrm{Cu}(\mathrm{II})$ ions from aqueous solutions by adsorption onto nettle after incomplete incineration (IIN) has been studied in batch mode. The experimental isotherm results have been fitted using Langmuir, Freundlich, Temkin and Dubinin-Radushkevich equations. A comparison of kinetic models applied to the adsorption of $\mathrm{Cu}(\mathrm{II})$ ions on the adsorbent was evaluated for the pseudo-first order, the pseudo-second order and Elovich kinetic models. The pseudo-second order kinetic model was found to correlate the experimental data well. To evaluate competitive adsorption the batch experiments were carried out among the $\mathrm{Cu}(\mathrm{II}), \mathrm{Pb}(\mathrm{II})$ and $\mathrm{Cd}(\mathrm{II})$. The affinity order for the ternary system was $\mathrm{Pb}(\mathrm{II})>\mathrm{Cu}(\mathrm{II})>\mathrm{Cd}(\mathrm{II})$. FTIR and SEM analysis indicated that IIN could be used as an efficient biosorbent whose chemical structure and morphology is not altered during adsorption process.
\end{abstract}

Keywords: biosorption, heavy metals, kinetic study, thermodynamic study, Urtica dioica $L$.

\section{INTRODUCTION}

Heavy metal pollution has become one of the biggest problems in the context of environmental pollution due to their solubility, mobility and ability to accumulate in the soil. Wastes with high content of metals directly or indirectly discharged into the environment which causes its pollution. [1]

\footnotetext{
a University of Niš, Faculty of Sciences and Mathematics, Department of Chemistry, 18000 Niš, Republic of Serbia

b University of Niš, Faculty of Occupational Safety, 18000 Niš, Republic of Serbia

*Corresponding author: dragance73@yahoo.com
} 
Chemical vapor deposition and electrochemical treatment are not effective for highly diluted solutions and produce a large amount of sludge. On other side, ion exchanges, as well as technology based on purification by membrane, belong to expensive technology.

All rigorous standards of allowable concentrations of contaminants and environmental protection have caused the quest for better and cheaper methods of purification of polluted water. For this purpose, develop various kinds of substances capable to adsorb pollutants. As a particularly significant adsorbent must be mentioned activated charcoal. Activated carbon can be produced starting from different precursors such as peat, wood, stone fruits, etc. [2-6]

The maximum allowed concentration of copper for drinking water which is regulated by the United States Environmental Protection Agency in 2010 is $1.3 \mathrm{mg} \mathrm{dm}^{-3}$. [1]

Lead belongs to the group of the highly toxic elements, with a cumulative-toxic effect. Prolonged exposure to low-level toxicity $\left(<240 \mu \mathrm{g} \mathrm{dm}^{-3}\right)$ can lead to various psychological disorders and learning disabilities among children.

Cadmium is one of the most dangerous poisons of the working and living environment. Once it enters the body, cadmium is transported into the blood by red blood cells and a highly molecular blood protein - albumin. The maximum allowed concentration for drinking water which is regulated by the United States Environmental Protection Agency in 2010 is $5 \times 10-3 \mathrm{mg} \mathrm{dm}^{-3}$. [1]

Heavy metal adsorption onto some biomass, such as nettle, grapevine, marigold, linden, geranium, chestnut and maple naturally dried [7], Salvinia [8], Ludwigia stolonifera [9], Urtica dioica and Sedum spectabile [10], nettle [11,12], Neem leaves [13].

Nettle is traditionally used as a medicinal plant. In modern phytotherapy are known different preparations based on nettles. Medicinal raw materials are leaves and above-ground part.[14] In the literature, is also known that this plant is used for phytoremediation. In several studies authors used a nettle ash as a low cost adsorbent for the removal heavy M(II) metals from aqueous solution. [11,12,15-17]

The aim of this study was to show that the product of incomplete combustion obtained from a disused plant material nettle can be used as a potentially inexpensive and readily available biosorbent for the removal of heavy metals from aqueous solutions. A model system for studying the biosorption was a solution of $\mathrm{M}(\mathrm{II})$ metal ions $(\mathrm{Cu}, \mathrm{Pb}$ and $\mathrm{Cd})$ concentration in the range of maximum concentration that could occur in polluted waters from the surrounding city of Nis due to industrial processes. The effect of various experimental parameters such as contact time, initial $\mathrm{Cu}$ (II) concentration, 
biosorbent dosage and metal ions competition has been investigated. The equilibrium data were fitted to Langmuir, Freundlich, Temkin, and DubininRadushkevich isotherm models, while the kinetics data were correlated according to various kinetics models (pseudo-first order, pseudo-secondorder and Elovich model).

\section{RESULTS AND DISCUSSION}

\section{FTIR characterization of nettle biosorbent}

FTIR spectra of raw nettle, after incomplete combustion, such as complete combustion and after adsorption treatment are given in Figure 1.

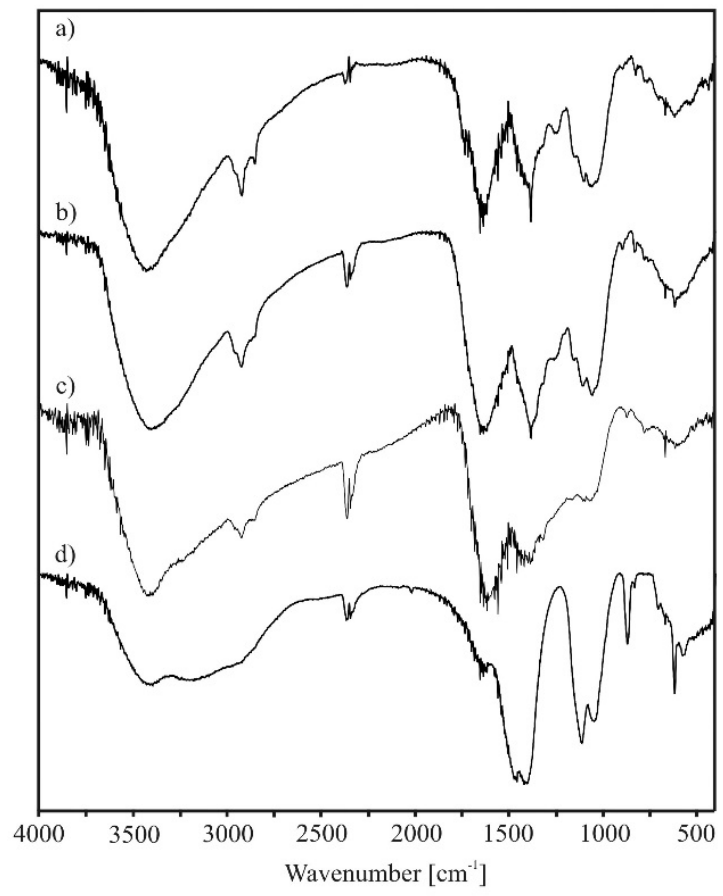

Figure 1. FTIR spectra of: a) raw nettle, b) after incomplete incineration nettle,

c) after $\mathrm{Cu}(\mathrm{II})$ adsorption treatment and d) after complete incineration

The spectrum of raw nettle shows characteristic adsorption bands for a plant material (Fig. 1a). A broad band between 3200 and $3600 \mathrm{~cm}^{-1}$ attributed to the hydroxyl groups in phenol and aliphatic structures, bands centered around $2920 \mathrm{~cm}^{-1}$, predominantly arising from $\mathrm{CH}$ stretching in $-\mathrm{CH}_{3}$ or 
$-\mathrm{CH}_{2}$ - groups, a band at $1640 \mathrm{~cm}^{-1}$ indicates the fingerprint region of $\mathrm{CO}, \mathrm{C}-\mathrm{O}$ and $\mathrm{O}-\mathrm{H}$ groups. The band at $1383 \mathrm{~cm}^{-1}$ corresponding to $\mathrm{C}-\mathrm{O}$ stretching. The region between 1250 and $1000 \mathrm{~cm}^{-1}$ is the fingerprint region, $\mathrm{OH}$, and $\mathrm{C}-\mathrm{H}$ bending vibration and $\mathrm{C}-\mathrm{O}$ stretching vibration absorption bands. The intense band at $1061 \mathrm{~cm}^{-1}$ can be assigned to the $\mathrm{C}-\mathrm{O}$ of alcohols and carboxylic acids. Bands in the region from 700 to $400 \mathrm{~cm}^{-1}$ are attributed to halogen compounds. [18-23] In the FTIR spectrum of incomplete burning/ incineration nettle shown in Fig. $1 \mathrm{~b}$ there is no significance changes compared to spectrum of raw plant material, which indicates that it is made incomplete incineration of plant, and all organic functional groups are put on hold. After completed incineration in oven $\left(500-600{ }^{\circ} \mathrm{C}\right.$ ) all organic matter (functional group) were removed from nettle, which are confirm with presentation of inorganic biomineral bands in FTIR spectra: $3400-3100 \mathrm{~cm}^{-1}$ Si-OH vibrations; $1636 \mathrm{~cm}^{-1}$ calcium oxalate; 1456 and $1419 \mathrm{~cm}^{-1}$ asymmetric calcite stretching; 1112 and $1052 \mathrm{~cm}^{-1}$ biogenic silica; $870 \mathrm{~cm}^{-1}$ out of plane deformation calcite; $618 \mathrm{~cm}^{-1}$, halogenides (Fig. 1d). [24]

The FTIR spectra for the copper loaded biosorbent (Fig. 1c) showed wavenumbers and intensity of some peaks that were shifted or substantially lower than those before biosorption. A band assigned to $\mathrm{O}-\mathrm{H}$ stretching vibrations showed a decrease in intensity and shift from 3420 to $3428 \mathrm{~cm}^{-1}$ probably indicating copper ions interacted with hydroxyl groups. A shifting of band from $1640 \mathrm{~cm}^{-1}$ to $1623 \mathrm{~cm}^{-1}$ indicates involvement of $\mathrm{CO}, \mathrm{C}-\mathrm{O}$ and $\mathrm{O}-\mathrm{H}$ groups in copper(II) binding. The band corresponding of $\mathrm{C}-\mathrm{O}$ stretching was shifted to $1450 \mathrm{~cm}^{-1}$, and the bands from region of 1250 and $1000 \mathrm{~cm}^{-1}$ showed a decrease in intensity (practically disappear in the spectrum), which also suggests the involvement of $\mathrm{C}-\mathrm{O}$ and $-\mathrm{OH}$ group in binding copper(II) ions. $[21,23]$

\section{SEM-EDX characterization of nettle biosorbent}

The morphological characteristics of biosorbent surfaces were examined by scanning electron microscopy (Fig. 2). It can be observed that material is of fibrous and stripes structure which is characteristic for cellulosic material. After incomplete incineration nettle structure became uneven rugged and porous. These structure characteristics allow better diffusion of solution and probably increase possibility for investigated metal ions to penetrate into the biosorbent and their adsorption onto numerous active sites of biosorbent. There are no differences in the biosorbent structure before and after copper adsorption, and the presence of adsorbed metal ion with SEM cannot be verified due to scale of this micrographs and the dimension of copper ion. 

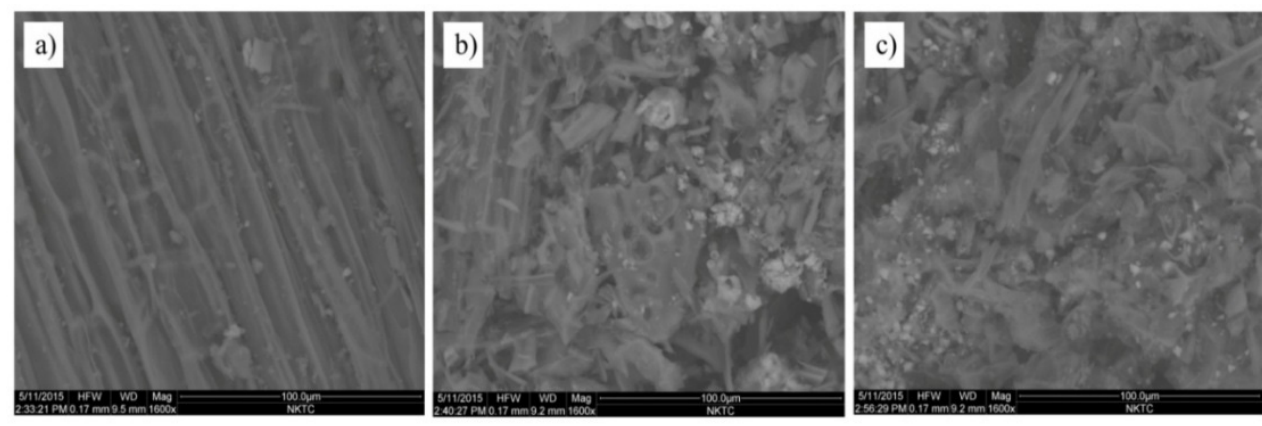

Figure 2. SEM micrographs of: a) raw nettle, b) after incomplete incineration nettle and $\mathrm{c}$ ) after $\mathrm{Cu}(\mathrm{II})$ adsorption treatment

EDX analysis of a raw nettle, after incomplete incineration nettle (hereafter IIN) and after biosorption of $\mathrm{Cu}(\mathrm{II})$ ions was shown in Figure $\mathrm{B}$. This analysis provides information about elemental content of investigation biomaterial. The presence of C (wt\% ca. 60), O (wt\% ca. 23) and K (wt\% ca. 14) as major elements and other minor elements ( $\mathrm{P}, \mathrm{S}, \mathrm{Cl}, \mathrm{Mg}$, and $\mathrm{Ca}$ ) indicate the chemical composition characteristic for plant material (Fig. 3a). Increase peak intensity (pi) from 1030 to 1740 and weight percent from $60 \%$ to $68 \%$ for C; and decrease the same parameters for O (pi: from 330 to 240; and wt: from $23 \mathrm{wt} \%$ to $14 \%$ ) compared to untreated nettle indicate incomplete burning treatment of biomaterial (Fig 3b). The presence of peak of copper (Fig 3c) indicate the adsorption of the metal ion to the surface of the nettle biosorbent.

(a)

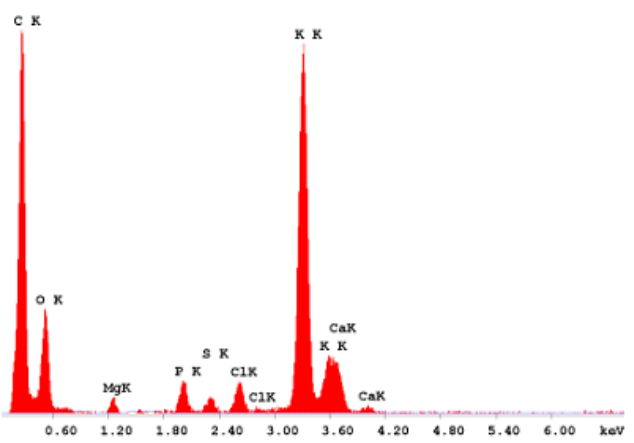

(b)

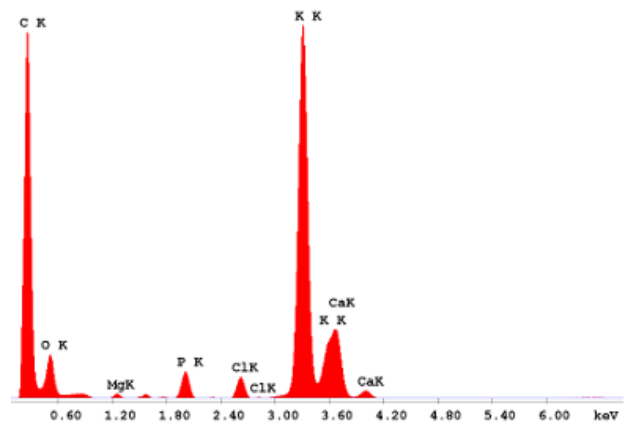

Figure 3. EDX spectra of: a) raw nettle, b) after incomplete incineration of nettle 
VLADIMIR D. DIMITRIJEVIĆ, MAJA N. STANKOVIĆ, DRAGAN M. ĐORĐEVIĆ, IVAN M. KRSTIĆ, MILICA G. NIKOLIĆ, ALEKSANDAR LJ. BOJIĆ, NENAD S. KRSTIĆ

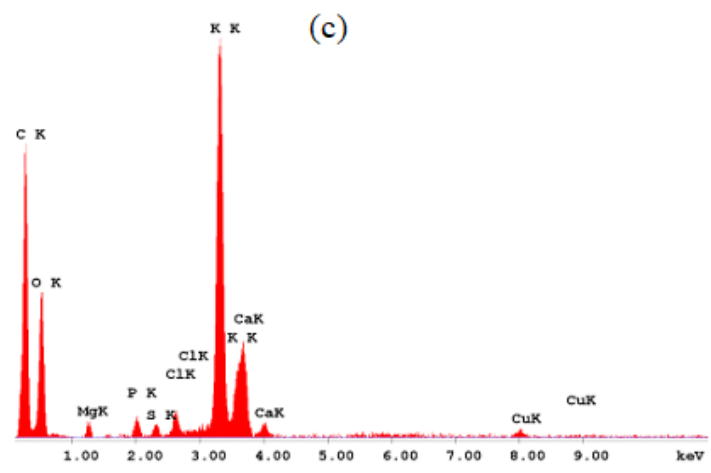

Figure 3. EDX spectra of c) after $\mathrm{Cu}(\mathrm{II})$ adsorption treatment

\section{Effect of biosorbent type on adsorption process}

The effect of contact time on the residual concentration of $\mathrm{Cu}(\mathrm{II})$ ions in aqueous solution with raw nettle and nettle after incomplete incineration is shown at Fig. 4.

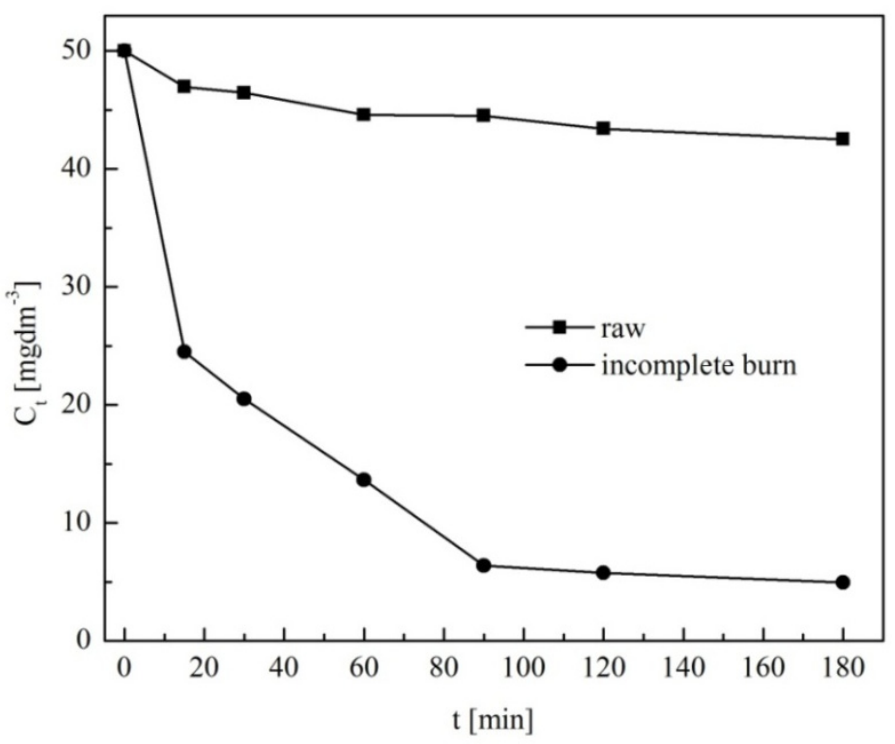

Figure 4. Effect of contact time on removal $\mathrm{Cu}(\mathrm{II})$ by raw nettle and nettle after incomplete incineration (initial $\mathrm{Cu}(\mathrm{II})$ concentration $50 \mathrm{mg} \mathrm{dm}^{-3}$, temp. $20 \pm 0.5^{\circ} \mathrm{C}, \mathrm{pH} 5.0 \pm 0.1$, biosorbent dose $4.0 \mathrm{~g} \mathrm{dm}^{-3}$ ) 
Experiments were performed with model wastewaters containing $\mathrm{Cu}(\mathrm{II})$ ions at an initial concentration of $50.0 \mathrm{mg} \mathrm{dm}^{-3}$, a biosorbent dose of $4.0 \mathrm{~g} \mathrm{dm}^{-3}$, at $20 \pm 0.5^{\circ} \mathrm{C}$ and $\mathrm{pH} 5.0$. These results indicate that raw nettle is not efficient biosorbent, but after incomplete incineration it became a very efficient biosorbent for removal $\mathrm{Cu}(\mathrm{II})$ ions from wastewater. The concentration of copper declined sharply with contact time in the first $10 \mathrm{~min}$, then decreased slightly to $90 \mathrm{~min}$, and after that reached equilibrium. The initial fast phase occurs due to a high availability of the number of active binding sites (functional groups) on the biosorbent surface, and it is typically controlled by the diffusion process from the solution to the surface. A further increase in contact time did not show a significant decrease of $\mathrm{Cu}$ (II) concentration, which occurs due to diffusion of the copper ions into the inner part of the biomass. [21]

\section{Effect of initial Cu(II) concentration}

The influence of initial $\mathrm{Cu}(\mathrm{II})$ concentration on pollutant removal from aqueous solution by INN $\left(4.0 \mathrm{~g} \mathrm{dm}^{-3}\right)$ was studied in the concentrations range from 10.0 to $200.0 \mathrm{mg} \mathrm{dm}^{-3}$ at $20 \pm 0.5^{\circ} \mathrm{C}$ and $\mathrm{pH} 5.0 \pm 0.1$. The effect of initial $\mathrm{Cu}$ (II) concentration on removal efficiency is shown in Fig. 5.

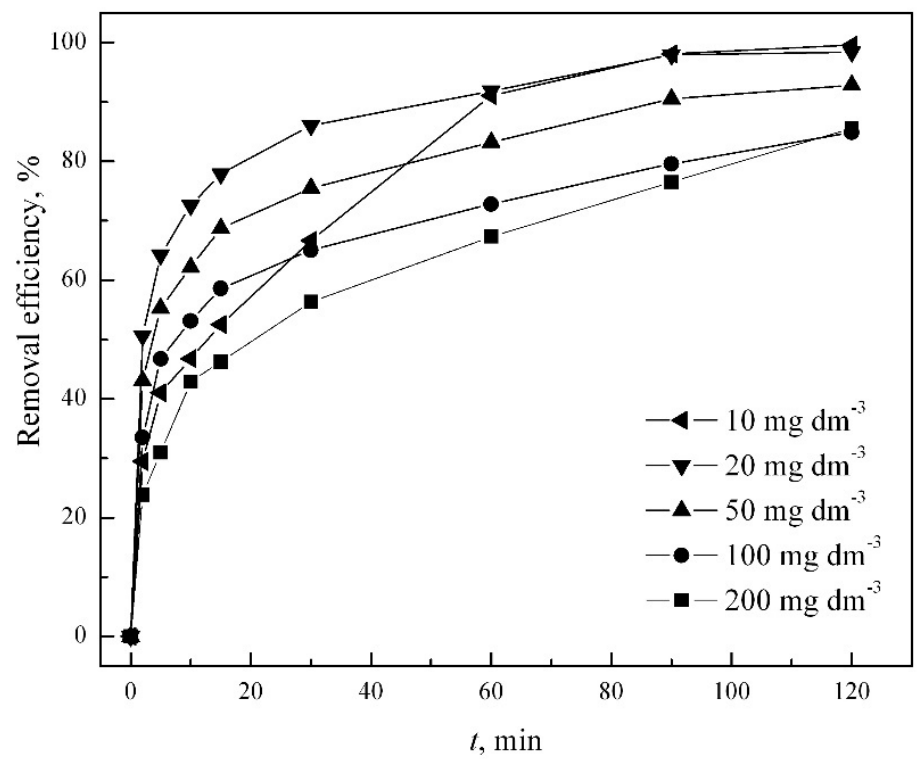

Figure 5. Effects of initial $\mathrm{Cu}$ (II) concentration on removal $\mathrm{Cu}$ (II) by IIN (initial Cu(II) concentration 10.0-200.0 mg dm${ }^{-3}$, temp. $20 \pm 0.5^{\circ} \mathrm{C}$, $\mathrm{pH} 5.0 \pm 0.1$, biosorbent dose $4.0 \mathrm{~g} \mathrm{dm}^{-3}$ ) 
VLADIMIR D. DIMITRIJEVIĆ, MAJA N. STANKOVIĆ, DRAGAN M. ĐORĐEVIĆ, IVAN M. KRSTIĆ,

MILICA G. NIKOLIĆ, ALEKSANDAR LJ. BOJIĆ, NENAD S. KRSTIĆ

The initial copper concentration is a driving force to overcome mass transfer resistance for metal ion transport between the solution and the surface of the adsorbent. The amount of $\mathrm{Cu}$ (II) uptake increased by increasing the initial $\mathrm{Cu}$ (II) concentration (Table 1), but adsorption percentages decrease with increase in the $\mathrm{Cu}$ (II) concentration. At low concentrations of copper(II) ions, greater availability of the exchangeable sites on the surface area interact with all adsorbate ions present in the solution more rapid reaching the almost $100 \%$ adsorption. On the other side saturation of the available active sites on the surface functional groups prevent further copper ion uptake with increase of $\mathrm{Cu}(\mathrm{II})$ concentration. [11]

\section{Effect of biosorbent dosage}

Batch experiments were performed at different biosorbent dosage ranging from 1.0 to $8.0 \mathrm{~g} \mathrm{dm}^{-3}$ in contact with model waste waters containing $\mathrm{Cu}$ (II) ions at an initial concentration of $50.0 \mathrm{mg} \mathrm{dm}^{-3}$ at $20 \pm 0.5^{\circ} \mathrm{C}$ and $\mathrm{pH}$ $5.0 \pm 0.1$. The influence of biosorbent dosage on removal efficiency is shown in Fig. 6.

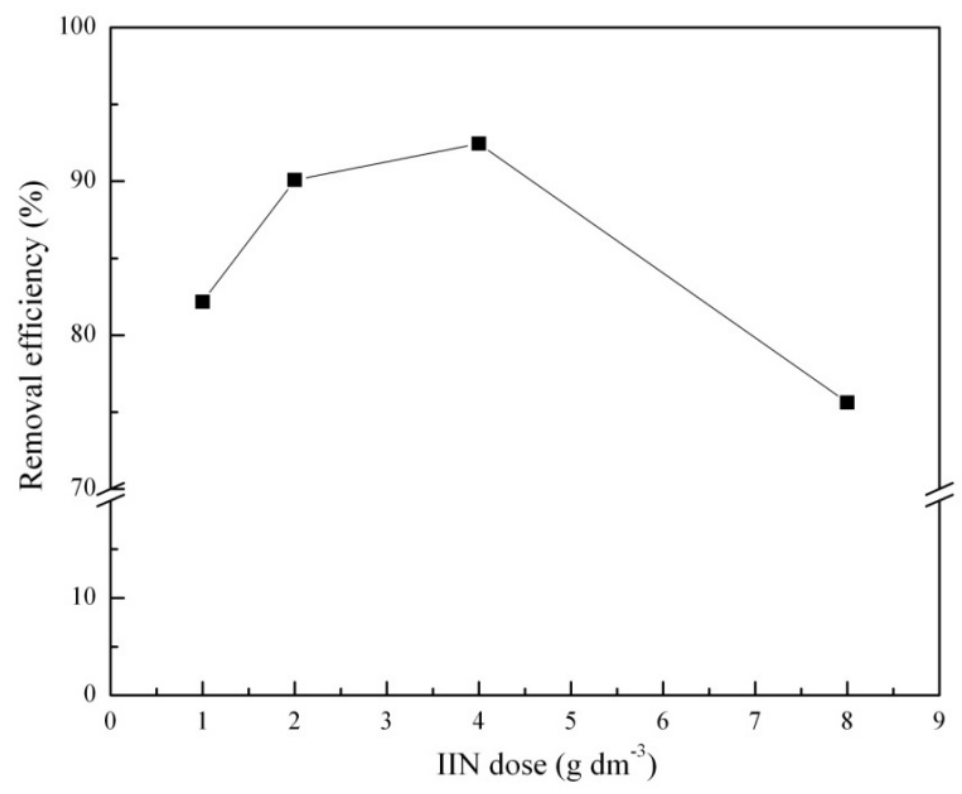

Figure 6. Effect of biosorbent dosage in a removal of $\mathrm{Cu}(\mathrm{II})$ ions (initial $\mathrm{Cu}(\mathrm{II})$ concentration $50.0 \mathrm{mg} \mathrm{dm}^{-3}$, temp. $20 \pm 0.5^{\circ} \mathrm{C}, \mathrm{pH} 5.0 \pm 0.1$ ) 
The biosorbent dosage determines the capacity of a biosorbent for a given initial concentration. The biosorption efficiency for $\mathrm{Cu}(\mathrm{II})$ ions as a function of biosorbent dosage was investigated. The efficiency of biosorption sharply increases with the biosorbent loading up to $4.0 \mathrm{~g} \mathrm{dm}^{-3}$. This result can be explained by the fact that the biosorption sites remain unsaturated during the biosorption because the number of sites available for biosorption increases by increasing the biosorbent dosage. [21] However, the copper uptake decreased when the biosorbent concentration exceeded $4.0 \mathrm{~g} \mathrm{dm}^{-3}$. For the optimum biosorbent dosage $4.0 \mathrm{~g} \mathrm{dm}^{-3}$ was taken. This dosage showed the highest removal efficiency as shown in Figure 6.

\section{Sorption kinetics}

Kinetics studies provide information on the rate of the sorption metal uptake which is very important for biosorption process design. [25]

\section{Pseudo-first-order model}

The pseudo-first order rate equation is represented in logarithmic form as: [26]

$$
\ln \left(q_{e}-q_{t}\right)=\ln q_{e}-k t
$$

where $q_{e}$ is the mass of metal ions adsorbed at equilibrium $\left(\mathrm{mg} \mathrm{g}^{-1}\right), \mathrm{q}_{\mathrm{t}}$ is the mass of metal adsorbed at time $t\left(\mathrm{mg} \mathrm{g}^{-1}\right)$, and $\mathrm{k}$ is the pseudo-first order reaction rate equilibrium constant $\left(\mathrm{min}^{-1}\right)$.

A straight line of $\ln \left(q_{\mathrm{e}}-q_{\mathrm{t}}\right)$ vs $t$ indicates that the pseudo-first order kinetics model should be applied. However, in a true pseudo-first order process, In $q_{\mathrm{e}}$ should be equal to the intercept and $k$ equal to the slope of plot of $\ln \left(q_{\mathrm{e}}-q_{\mathrm{t}}\right)$ against $t$, respectively.

\section{Pseudo-second-order model}

The pseudo-second-order equation based on equilibrium adsorption can be expressed in linearized form as [27]

$$
\frac{t}{q_{t}}=\frac{1}{k_{2} q_{e}^{2}}+\frac{1}{q_{e}} t
$$

where $k_{2}$ is the pseudo-second order reaction rate equilibrium constant $\left(\mathrm{g} \mathrm{mg}^{-1} \mathrm{~min}^{-1}\right)$. For the applicability of the pseudo-second-order kinetics model a plot of $t / q_{t}$ against $t$ should give a linear relationship. 
VLADIMIR D. DIMITRIJEVIĆ, MAJA N. STANKOVIĆ, DRAGAN M. ĐORĐEVIĆ, IVAN M. KRSTIĆ,

MILICA G. NIKOLIĆ, ALEKSANDAR LJ. BOJIĆ, NENAD S. KRSTIĆ

Table 1. Pseudo-first, pseudo-second-order and Elovich model parameters for biosorption of $\mathrm{Cu}(\mathrm{II})$ ions using IIN

\begin{tabular}{|c|c|c|c|c|c|}
\hline & \multicolumn{5}{|c|}{ Concentration $\mathrm{Cu}(\mathrm{II}), \mathrm{mg} \mathrm{dm}^{-3}$} \\
\hline & 10.0 & 20.0 & 50.0 & 100.0 & 200.0 \\
\hline$q_{e}^{e x p}$ & 2.49 & 4.92 & 11.60 & 21.22 & 42.81 \\
\hline \multicolumn{6}{|c|}{ Pseudo-first model } \\
\hline $\mathrm{k}_{1}$ & 0.0359 & 0.0485 & 0.0338 & 0.0256 & 0.0312 \\
\hline$q_{e}$ & 2.11 & 2.80 & 6.64 & 12.52 & 15.53 \\
\hline $\mathrm{R}^{2}$ & 0.9941 & 0.9644 & 0.9665 & 0.9560 & 0.5907 \\
\hline \multicolumn{6}{|c|}{ Pseudo-second model } \\
\hline $\mathrm{k}_{2}$ & 0.0296 & 0.0527 & 0.0161 & 0.0070 & 0.0075 \\
\hline $\mathrm{q}_{\mathrm{e}}$ & 2.76 & 5.04 & 11.91 & 21.65 & 43.40 \\
\hline $\mathrm{R}^{2}$ & 0.9950 & 0.9995 & 0.9987 & 0.9974 & 0.9990 \\
\hline \multicolumn{6}{|c|}{ Elovich model } \\
\hline$\beta$ & 2.1277 & 1.7146 & 0.6629 & 0.3353 & 0.1547 \\
\hline$\alpha$ & 0.7681 & 27.1794 & 27.5691 & 26.088 & 25.749 \\
\hline $\mathrm{R}^{2}$ & 0.9783 & 0.9957 & 0.9987 & 0.9970 & 0.9449 \\
\hline
\end{tabular}

The values of $\mathrm{q}_{\mathrm{e}, \exp }$ and the $\mathrm{q}_{\mathrm{e}, \mathrm{cal}}$ from the pseudo-second-order kinetic model were very close to one another. The calculated coefficients of determination for pseudo-second-order kinetics $\left(R^{2}\right)$ were closer to 1 than coefficient for the pseudo-first-order kinetics. Overall conclusion is that the pseudo second-order mechanism is predominant and that the adsorption process of the copper(II) ions is most likely to be controlled by the chemisorption process. $[11,12]$

\section{Elovich model}

The Elovich model describes many of reaction mechanisms including bulk and surface diffusion and the activation and deactivation of catalytic surfaces: [28]

$$
q_{t}=\frac{1}{\beta}(\ln \alpha \beta)+\frac{1}{\beta} \ln t
$$

where $\alpha$ is the initial adsorption rate $\left(\mathrm{mg} \mathrm{g}^{-1} \min ^{-1}\right)$, and $\beta$ is the desorption constant $\left(\mathrm{g} \mathrm{mg}^{-1}\right)$. If the Elovich equation is applicable with a slope of $(1 / \beta)$ and an intercept of $(1 / \beta) \ln (\alpha \beta)$, plot of $q_{t}$ versus $\ln t$ should give a linear relationship. 

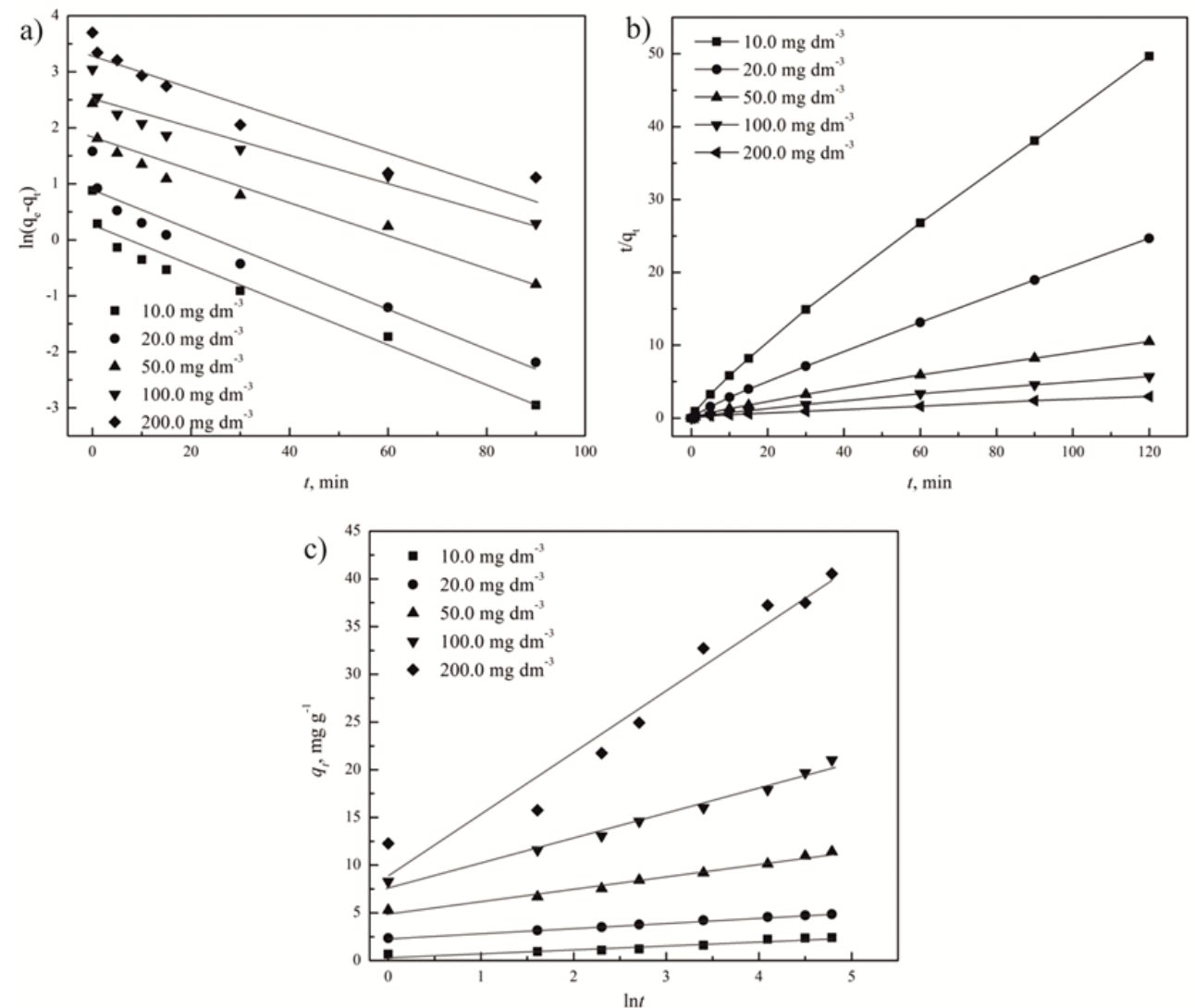

Figure 7. Kinetic models a) pseudo-first, b) pseudo-second, c) Elovich

Fig. 7c depicts a plot of the Elovich equation for the investigated data. In this case, a linear relationship between $\mathrm{Cu}(\mathrm{II})$ biosorbed, $q_{t}$ and $\mathrm{Int}$ was not obtain for overall concentration range. However, good correlation with the Elovich model was observed for initial copper(II) concentrations of $20.0 \mathrm{mg}$ $\mathrm{dm}^{-3}, 50.0 \mathrm{mg} \mathrm{dm}^{-3}$ and $100.0 \mathrm{mg} \mathrm{dm}^{-3}$ with determination coefficients of $0.9957,0.9987$ and 0.9970 , respectively. Table 1 lists the kinetic constants obtained from the Elovich equation. It can be observed that with increasing the initial copper(II) concentration from 10.0 to $200.0 \mathrm{mg} \mathrm{dm}^{-3}$ the value of $\beta$ decreased from 2.1277 to 0.1547 . Nevertheless, the determination coefficients obtained from Elovich equation are lower than those calculated from the pseudosecond-order equation. 
VLADIMIR D. DIMITRIJEVIĆ, MAJA N. STANKOVIĆ, DRAGAN M. ĐORĐEVIĆ, IVAN M. KRSTIĆ, MILICA G. NIKOLIĆ, ALEKSANDAR LJ. BOJIĆ, NENAD S. KRSTIĆ

\section{Adsorption isotherms}

Adsorption isotherm is a graphical representation that maps the distribution of adsorbable solute between the liquid and solid phases at various equilibrium concentrations. [29] The adsorption isotherm data have been got by varying the initial metal concentration while the other parameters are kept constant. Besides to the Langmuir and Freundlich isotherm models, which are commonly used in describing adsorption, the experimental data were fitted to the Temkin and Dubinin-Radushkevich isoterm models.

\section{Langmuir isotherm model}

This isotherm model describes quantitatively the formation of a monolayer adsorbate on the outer surface of the adsorbent, and after that no further adsorption takes place. Thus, the Langmuir represents the equilibrium distribution of metal ions between the solid and liquid phases. [30] The Langmuir model assumes that the uptake of metal ions occurs on a homogeneous surface by monolayer adsorption without any interaction between adsorbed ions. [31] Based upon these assumptions, Langmuir represented the following equation:

$$
\mathrm{q}_{\mathrm{e}}=\frac{\mathrm{q}_{\max } \mathrm{K}_{\mathrm{L}} \mathrm{C}_{\mathrm{e}}}{1+\mathrm{K}_{\mathrm{L}} \mathrm{C}_{\mathrm{e}}}
$$

The Langmuir parameters can be determined from a linearized form, by plotting $C_{e} / q_{\mathrm{e}}$ vs. $C_{\mathrm{e}}$ :

$$
\frac{\mathrm{C}_{\mathrm{e}}}{\mathrm{q}_{\mathrm{e}}}=\frac{1}{\mathrm{~K}_{\mathrm{L}} \mathrm{q}_{\max }}+\frac{1}{\mathrm{q}_{\max }} \mathrm{C}_{\mathrm{e}}
$$

where $\mathrm{C}_{\mathrm{e}}$ is the equilibrium concentration of adsorbate $\left(\mathrm{mg} \mathrm{dm}^{-3}\right), \mathrm{q}_{\max }$ is the Langmuir equilibrium constant related to maximum monolayer coverage capacity $\left(\mathrm{mg} \mathrm{g}^{-1}\right)$, and $\mathrm{K}_{\mathrm{L}}$ is the Langmuir constant which is related to the enthalpy of adsorption $\left(\mathrm{dm}^{-3} \mathrm{mg}^{-1}\right)$.

The values of $q_{\max }$ and $K_{L}$ were calculated from the slope and intercept of the Langmuir plot of $C_{e} / q_{e}$ vs. $C_{e}$. [31] This is the most often used isotherm applied for explaining the adsorption equilibrium. However, the Langmuir isotherm offers no insights into the mechanism aspects of biosorption. [32]

\section{Freundlich isotherm model}

This is commonly used to describe the adsorption characteristics for the heterogeneous surface. It is represented by the equation: [33] 
THE PRELIMINARY ADSORPTION INVESTIGATION OF URTICA DIOICA L. BIOMASS MATERIAL AS A POTENTIAL BIOSORBENT FOR HEAVY METAL IONS

$$
\mathrm{q}_{\mathrm{e}}=\mathrm{K}_{\mathrm{F}} \mathrm{C}^{\frac{1}{\mathrm{n}}}
$$

where $\mathrm{K}_{\mathrm{F}}$ is Freundlich isotherm constant $\left(\mathrm{mg} \mathrm{g}^{-1}\right)$, and $\mathrm{n}$ is adsorption intensity.

This model assumes that the uptake of metal ions occurs by multilayer adsorption where the stronger binding sites are occupied first and the binding strength decreases with increasing degree of site occupation. [34,35] This reason it is more indicative for the physical mechanism of adsorption.

Freundlich empirical adsorption isotherm equation can be expressed in the logarithmic, linear form as:

$$
\log q_{e}=\log K_{F}+\frac{1}{n} \log C_{e}
$$

The constant $\mathrm{K}_{\mathrm{F}}$ is an approximate indicator of adsorption capacity, while $1 / n$ is a function of the strength of adsorption in the adsorption process. [36] If $\mathrm{n}=1$ then the partition between the two phases are independent of the concentration. If value of $1 / n$ is below one it indicates a normal adsorption. On the other side, $1 / n$ being above one indicates cooperative adsorption. [37] 1/n is a heterogeneity parameter, the smaller $1 / n$, the greater heterogeneity should be expected. This expression reduces to a linear adsorption isotherm when $1 / n=1$. If $n$ lies between 1 and 10 , this indicates a favorable sorption process. [38]

\section{Temkin isotherm model}

This isotherm contains a factor that explicitly taking into the account of adsorbent-adsorbate interactions. By ignoring the extremely low and large value of concentrations, the model assumes that heat of adsorption (function of temperature) of all molecules in the layer would decrease linearly rather than logarithmic with coverage. $[30,31,34]$ This equation implies that the adsorption is characterized by a uniform distribution of binding energies, up to some maximum binding energy. [39] The model is given by the following equation: [30,31]

$$
\begin{aligned}
& q_{e}=\frac{R T}{b_{T}} \ln \left(A_{T} C_{e}\right) \\
& q_{e}=\frac{R T}{b_{T}} \ln A_{T}+\frac{R T}{b_{T}} \ln C_{e}
\end{aligned}
$$


where $A_{T}$ is Temkin isotherm equilibrium binding constant $\left(\mathrm{dm}^{3} \mathrm{~g}^{-1}\right)$ which corresponds to the maximum binding energy, $b_{T}$ is Temkin isotherm constant related to heat of sorption $\left(\mathrm{J} \mathrm{mol}^{-1}\right), \mathrm{R}$ is universal gas constant $\left(8.314 \mathrm{~J} \mathrm{~mol}^{-1} \mathrm{~K}^{-1}\right)$, and $\mathrm{T}$ is absolute temperature $(\mathrm{K})$.

\section{Dubinin-Radushkevich isotherm model}

The Dubinin-Radushkevish isotherm was chosen to estimate the characteristics porosity of the biomass and the apparent energy of adsorption. [40] Dubinin-Radushkevich isotherm is generally applied to express the adsorption mechanism with a Gaussian energy distribution onto a heterogeneous surface. $[41,42]$ The model has often successfully fitted high solute activities and the intermediate range of concentrations data well. The model is represented by the equation below:

$$
\begin{aligned}
& \mathrm{q}_{\mathrm{e}}=\left(\mathrm{q}_{\mathrm{s}}\right) \exp \left(-\mathrm{K}_{\mathrm{ad}} \varepsilon^{2}\right) \\
& \varepsilon=\left[\mathrm{R} \operatorname{Tln}\left(1+\frac{1}{\mathrm{C}_{\mathrm{e}}}\right)\right]
\end{aligned}
$$

where $\mathrm{q}_{\mathrm{s}}$ is theoretical isotherm saturation capacity $\left(\mathrm{mg} \mathrm{g}^{-1}\right), \mathrm{K}_{\mathrm{ad}}$ is Dubinin Radushkevich isotherm constant $\left(\mathrm{mol}^{2} \mathrm{~kJ}^{-2}\right)$, and $\varepsilon$ is Dubinin-Radushkevich isotherm constant.

Dubinin-Radushkevich isotherm equation can be expressed in the logarithmic, linear form as:

$$
\ln q_{e}=\ln q_{s}-K_{a d} \varepsilon^{2}
$$

Table 2 shows the isotherm parameters for Langmuir, Freundlich, Temkin and Dubinin-Radushkevich isotherms. The fitting of the data to the Langmuir, Freundlich, Temkin and Dubinin-Radushkevich isotherms shows that the biosorption of $\mathrm{Cu}(\mathrm{II})$ ions by IIN follows Freundlich model better than the others based on the coefficients of determination $\left(R^{2}\right)$. This phenomenon suggests that multilayer sorption takes place on the surface of biomass. KF and $\mathrm{n}$ were calculated from the slope of the Freundlich plot and were found to be $5.2588 \mathrm{~L} \mathrm{mg-1}$ and 1.8468 , respectively. The value of KF and $n$ shows high adsorption capacity i.e. easy separation of heavy metal ions from wastewater. The fact that the magnitude of $n$ (which is related to the distribution of bonded ions on the sorbent surface) is greater than 1 represents that adsorption of $\mathrm{Cu}(\mathrm{II})$ is favorable. $[11,12,23]$ 
THE PRELIMINARY ADSORPTION INVESTIGATION OF URTICA DIOICA L. BIOMASS MATERIAL AS A POTENTIAL BIOSORBENT FOR HEAVY METAL IONS
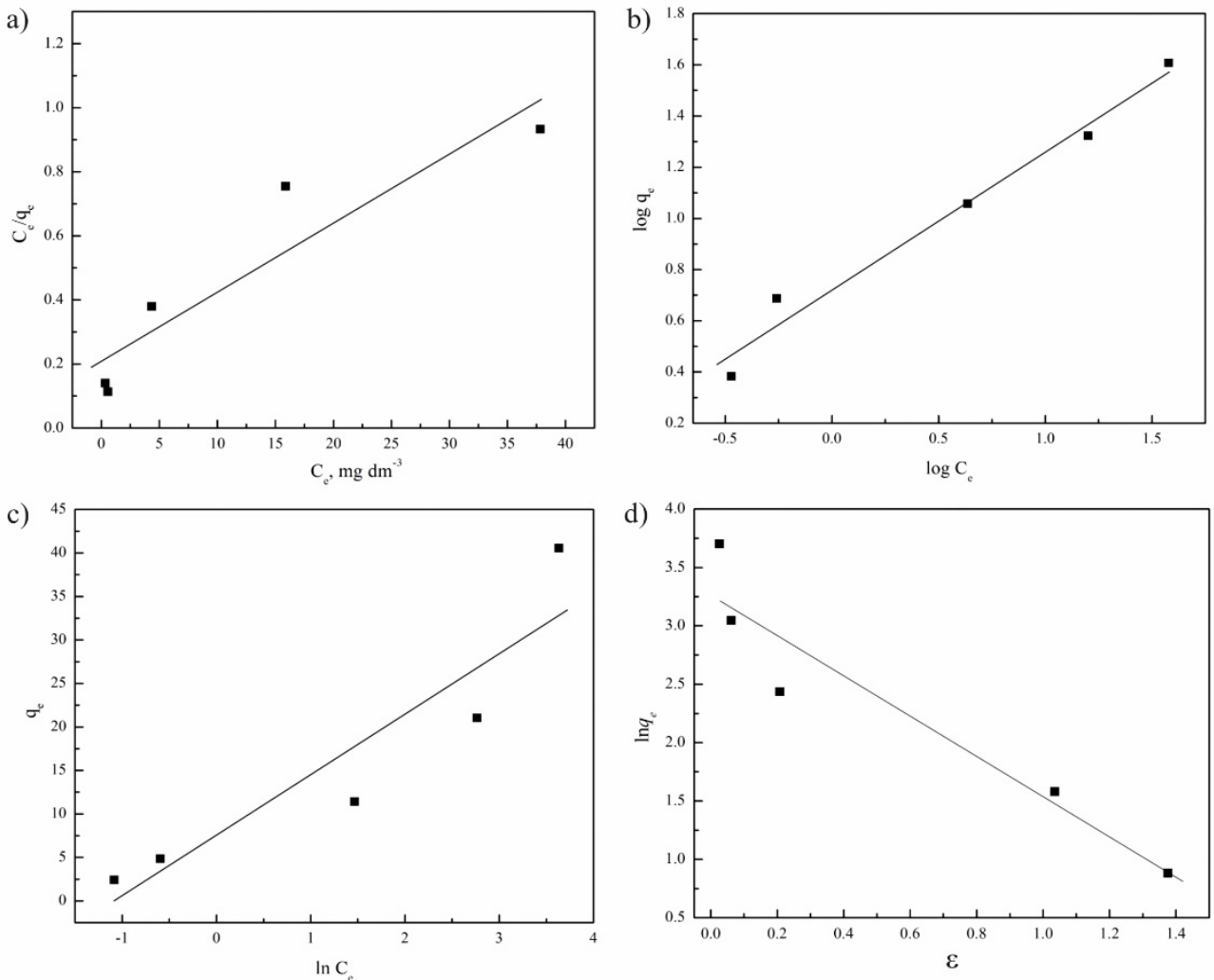

Figure 8. The isotherm model plots for adsorption $\mathrm{Cu}(\mathrm{II})$ ions onto IIN:

a) Langmuir, b) Freundlich, c) Temkin, and d) Dubinin-Radushkevich

Table 2. Langmuir, Freundlich, Temkin and Dubinin-Radushkevich parameters for the adsorption isotherms of $\mathrm{Cu}(\mathrm{II})$ by IIN

\begin{tabular}{|l|c|c|c|}
\hline \multicolumn{1}{|c|}{ Isotherms } & \multicolumn{3}{c|}{ Constants } \\
\hline Langmuir & $\mathrm{q}_{\max }\left(\mathrm{mg} \mathrm{g}^{-1}\right)$ & $\mathrm{K}_{\mathrm{L}}\left(\mathrm{L} \mathrm{mg}^{-1}\right)$ & $\mathrm{R}^{2}$ \\
\hline $\mathrm{C}_{\mathrm{e}} / \mathrm{q}_{\mathrm{e}}=1 / \mathrm{K}_{\mathrm{L}} \mathrm{q}_{\max }+\mathrm{C}_{\mathrm{e}} / \mathrm{q}_{\max }$ & 46.47 & 0.1023 & 0.8193 \\
\hline Freundlich & $\mathrm{n}$ & $\mathrm{K}_{\mathrm{F}}\left(\mathrm{L} \mathrm{mg}^{-1}\right)$ & \\
\hline log $\mathrm{q}_{\mathrm{e}}=\log \mathrm{K}_{\mathrm{F}}+(1 / \mathrm{n}) \log \mathrm{C}_{\mathrm{e}}$ & 1.8468 & 5.2588 & 0.9698 \\
\hline Temkin & $\mathrm{bT}_{\mathrm{T}}\left(\mathrm{kJ} \mathrm{mol}^{-1}\right)$ & $\mathrm{A}_{\mathrm{T}}\left(\mathrm{L} \mathrm{mg}^{-1}\right)$ & \\
\hline $\mathrm{q}_{\mathrm{e}}=\left(\mathrm{RT} / \mathrm{b}_{\mathrm{T}}\right) \ln \mathrm{A}_{\mathrm{T}}+\left(\mathrm{RT} / \mathrm{b}_{\mathrm{T}}\right) \mathrm{InC}_{\mathrm{e}}$ & 352.64 & 2.9208 & 0.8041 \\
\hline Dubinin-Radushkevich & $\mathrm{q}_{\mathrm{s}}$ & $\mathrm{K}_{\mathrm{ad}}\left(\mathrm{mol}^{2} \mathrm{~kJ}^{-2}\right)$ & \\
\hline Inq $_{\mathrm{e}}=\operatorname{lnq}_{\mathrm{S}}-\mathrm{K}_{\mathrm{ad}} \varepsilon^{2}$ & 26.08 & $2.86 \times 10^{-7}$ & 0.8741 \\
\hline
\end{tabular}


VLADIMIR D. DIMITRIJEVIĆ, MAJA N. STANKOVIĆ, DRAGAN M. ĐORĐEVIĆ, IVAN M. KRSTIĆ, MILICA G. NIKOLIĆ, ALEKSANDAR LJ. BOJIĆ, NENAD S. KRSTIĆ

\section{Adsorption behaviour in ternary solutions}

Wastewaters usually contain more than one metal ion and the examination of multiple metal interactions simultaneously is very important for precise interpretation of adsorption data. [43] The competitive adsorption among the $\mathrm{Cu}(\mathrm{II}), \mathrm{Pb}(\mathrm{II})$ and $\mathrm{Cd}(\mathrm{II})(1: 1: 1)$ in the ternary systems were conducted in batch systems with initial total concentration of $50.0 \mathrm{mg} \mathrm{dm}^{-3}$ and the biosorption was performed in the same conditions as it is described for a single ion solution. The single metal ion removal efficiency of IIN was $92.0 \%$, $86.8 \%$, and $99.9 \%$ for $\mathrm{Cu}(\mathrm{II}), \mathrm{Cd}(\mathrm{II})$ and $\mathrm{Pb}(\mathrm{II})$, respectively. The efficiency of metal removal of IIN were found to be $77.4 \%, 66.6 \%$ and $93.0 \%$ for $\mathrm{Cu}(\mathrm{II})-$ $\mathrm{Cd}(\mathrm{II})-\mathrm{Pb}$ (II) system (Fig. 9). Therefore, adsorption order in ternary system was found to be $\mathrm{Pb}(\mathrm{II})>\mathrm{Cu}(\mathrm{II})>\mathrm{Cd}(\mathrm{II})$, which is in agreement with previous studies. [44-47] These results indicated the highest decline of $20 \%$ in removal efficiency for $\mathrm{Cd}$ (II) followed by $15 \%$ for $\mathrm{Cu}(\mathrm{II})$ and $6 \%$ for $\mathrm{Pb}$ (II) in comparison to single metal system. It has been already concluded that the metal with the highest uptake capacity in the single metal system showed greater effect of inhibition on the biosorption of other metal ions in the multi-metal system, and when the lead ions exist in aqueous solution, the uptake of copper and cadmium decreased significantly. [48]

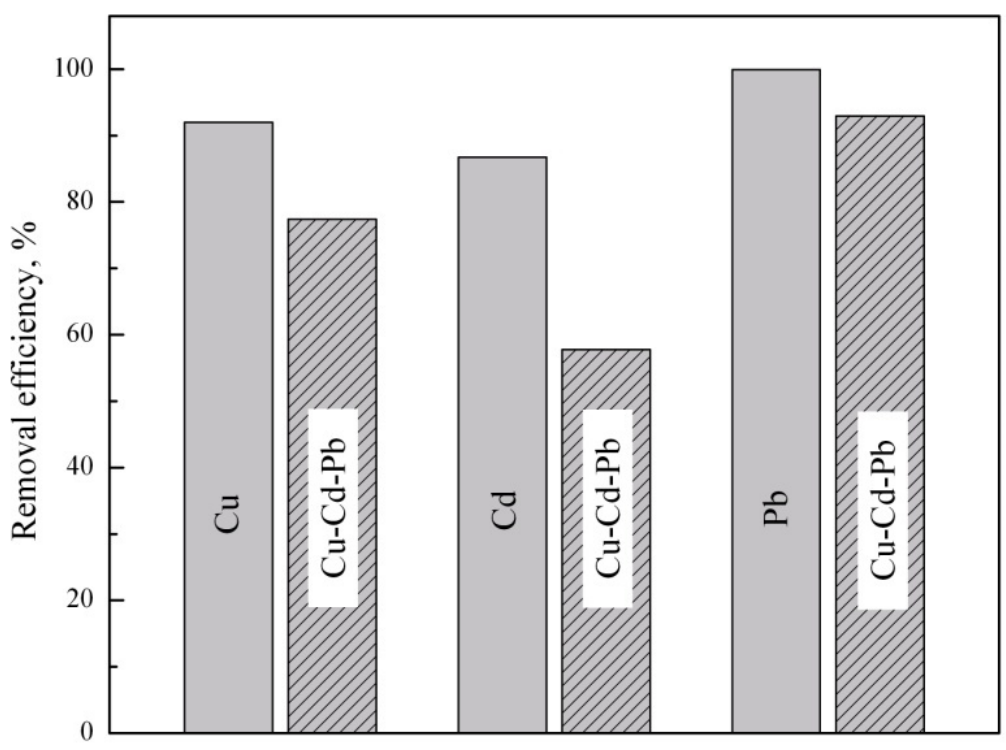

Figure 9. Removal efficiency of IIN for $\mathrm{Cu}(\mathrm{II}), \mathrm{Cd}(\mathrm{II})$ and $\mathrm{Pb}$ (II) ions for the sorption from the single-metal system and ternary-metals system 
THE PRELIMINARY ADSORPTION INVESTIGATION OF URTICA DIOICA L. BIOMASS MATERIAL AS A POTENTIAL BIOSORBENT FOR HEAVY METAL IONS

\section{CONCLUSIONS}

The present study indicated that the nettle after incomplete incineration (IIN) is an effective adsorbent for the removal of $\mathrm{Cu}(\mathrm{II})$ from aqueous solutions. SEM results indicate that surface of raw material has fibrous structure. IIN structure became unequally rugged and porous which presents a suitable morphological profile to bind $\mathrm{Cu}(\mathrm{II})$ ions. The effect of contact time on the residual concentration of $\mathrm{Cu}(\mathrm{II})$ ions in aqueous solution with raw nettle and IIN indicated that raw nettle is not efficient biosorbent, but after incomplete incineration it became very efficient. Batch experiments with different initial $\mathrm{Cu}$ (II) concentrations showed that copper uptake was increased by increasing the initial $\mathrm{Cu}(\mathrm{II})$ concentration, but, in the same time, removal efficiency decreases. The optimum biosorbent dosage was determined to be $4.0 \mathrm{~g} \mathrm{dm}^{-3}$. The sorption kinetics followed the pseudo-second order model. The batch adsorption data was successfully correlated with Freundlich isotherm model $\left(\mathrm{R}^{2}=0.9698\right)$. The competitive adsorption of $\mathrm{Cu}(\mathrm{II}), \mathrm{Pb}(\mathrm{II})$ and $\mathrm{Cd}(\mathrm{II})(1: 1: 1)$ in the ternary systems indicated that in all cases, there was an inhibitory effect of one metal on binding others and that the adsorption order was $\mathrm{Pb}(\mathrm{II})>$ $\mathrm{Cu}(\mathrm{II})>\mathrm{Cd}(\mathrm{II})$.

Nettle is very cheap material and the created sludge could be easily eliminated so nettle can be used as a potentially good biosorbent for the removal of heavy metals from wastewaters.

\section{EXPERIMENTAL SECTION}

\section{Reagents and Chemicals}

All chemicals $\left(\mathrm{CuSO}_{4} \times 5 \mathrm{H}_{2} \mathrm{O}, \mathrm{Pb}\left(\mathrm{NO}_{3}\right)_{2}, \mathrm{Cd}\left(\mathrm{NO}_{3}\right)_{2}\right.$, Merck) were of analytical grade and used without further purification. Deionized water $(<5 \mu \mathrm{S}$ $\mathrm{cm}^{-1}$ ) was used to prepare all aqueous solutions. Standard stock solutions of metal ions of $1000 \mathrm{mg} \mathrm{dm}^{-3}$ were used to prepare appropriate concentrations for the sorption studies. The $\mathrm{pH}$ of the solutions was adjusted $\mathrm{pH}$-metrically to the required value with nitric acid or sodium hydroxide $(0.1 / 0.01 \mathrm{M})$, without buffering. The $\mathrm{pH}$ of solutions was determined by a SensION3 (HACH, USA) $\mathrm{pH}$ meter.

\section{Preparation of biosorbent}

Biosorbent was obtained by incomplete incineration of dried nettle in covered porcelain pot. Nettle of the same levels of vegetation were collected from localities in vicinity of city of Niš (Serbia) and air dried prior to testing. 
VLADIMIR D. DIMITRIJEVIĆ, MAJA N. STANKOVIĆ, DRAGAN M. ĐORĐEVIĆ, IVAN M. KRSTIĆ, MILICA G. NIKOLIĆ, ALEKSANDAR LJ. BOJIĆ, NENAD S. KRSTIĆ

\section{FTIR Characterization of biosorbent}

The functional groups available on the surface of nettle before and after preparation, as well as adsorption of $\mathrm{Cu}(\mathrm{II})$ ions were detected by $\mathrm{KBr}$ technique using FTIR spectroscopy (Bomem Hartman \& Braun MB-100 spectrometer). The spectra were recorded at room temperature in a range from 4000 to $400 \mathrm{~cm}^{-1}$. The $\mathrm{KBr}$ pellets were prepared from $1.5 \mathrm{mg}$ of finely powdered biosorbent dispersed in $150 \mathrm{mg}$ of anhydrous $\mathrm{KBr}$. The obtained FTIR spectra were analyzed using ACD/Labs 10 software.

\section{SEM-EDX Characterization of biosorbent}

A Scanning Electron Microscope (FEI Quanta 200 microscope) was used to examine the surface morphology of the biosorbent. An energy dispersive X-ray spectrometer with the scanning electronic microscope (SEM-EDX) was used to determine the chemical composition of the biomass before and after metal uptake.

\section{The batch adsorption experiments}

The adsorption experiments were conducted in $250 \mathrm{~cm}^{3}$ Erlenmeyer flasks, containing $125 \mathrm{~cm}^{3}$ different concentrations (from 10.0 to $400.0 \mathrm{mg}$ $\mathrm{dm}-3$ ) of the model solution containing $\mathrm{Cu}(\mathrm{II})$ ions during $120 \mathrm{~min}$. Aliquots of solutions were withdrawn at preset time intervals, the biomaterial was removed by filtration through a $0.45 \mu \mathrm{m}$ membrane filter and the filtrates were analyzed for metal ions. All experiments were conducted at ambient temperature $\left(20.0 \pm 0.5^{\circ} \mathrm{C}\right)$, at initial $\mathrm{pH} 5.0 \pm 0.1$ and carried out in triplicates. The experiments were performed using magnetic stirrer on $200 \mathrm{rpm}$.

Competitive biosorption of $\mathrm{Cu}(\mathrm{II}), \mathrm{Pb}(\mathrm{II})$ and $\mathrm{Cd}(\mathrm{II})$ was investigated in ternary system, in $250 \mathrm{~cm} 3$ Erlenmeyer flasks containing metals in mass ratio $1: 1: 1$ with total concentration of $50 \mathrm{mg} \mathrm{dm}^{-3}$ to avoid increasing of the ionic strength compared to single metal experiment. The experiment was performed during 120 min period.

The concentrations of residual $\mathrm{M}(\mathrm{II})$ ions in the solution before and after adsorption were determined by using an atomic absorption spectrophotometer (AASAnalyst 300, Perkin-Elmer, USA) at standard wavelengths for investigated metals.

The adsorption capacity of the biosorbent, $\mathrm{q}_{\mathrm{e}}\left(\mathrm{mg} \mathrm{g}^{-1}\right)$, at equilibrium was calculated as:

$$
q_{e}=\frac{\left(\mathrm{C}_{0}-\mathrm{C}_{\mathrm{e}}\right) \mathrm{V}}{\mathrm{m}}
$$

where qe is the amount of $\mathrm{M}(\mathrm{II})$ ion adsorbed per unit weight of the adsorbent, $V$ is the volume of solution, $C_{0}$ is the initial concentration of metal ion $\left(\mathrm{mg} \mathrm{dm}^{-3}\right)$, $C_{e}$ is the equilibrium metal ion concentration $\left(\mathrm{mg} \mathrm{dm}^{-3}\right)$, and $\mathrm{m}$ is the mass of the adsorbent $(\mathrm{g})$. 
THE PRELIMINARY ADSORPTION INVESTIGATION OF URTICA DIOICA L. BIOMASS MATERIAL AS A POTENTIAL BIOSORBENT FOR HEAVY METAL IONS

The metal removal efficiency, RE (\%), of the adsorbent was estimated according to the following equation:

$$
R E=\frac{\mathrm{C}_{0}-\mathrm{C}_{\mathrm{e}}}{\mathrm{C}_{0}} \times 100 \%
$$

where $\mathrm{C}_{0}$ and $\mathrm{C}_{\mathrm{e}}$ are the initial and equilibrium concentrations $\left(\mathrm{mg} \mathrm{dm}^{-3}\right)$ of $M(I I)$ ions in solution, respectively.

\section{ACKNOWLEDGMENTS}

This work was supported by the Ministry of Education, Science and Technological Development of the Republic of Serbia under Grant TR34008.

\section{REFERENCES}

1. R.S. Nikolić, J.M. Jovanović, G.M. Kocić, N.S. Krstić, Glutathione and Lipoic Acid Benefit Effects on Liver, Kidney, Brain and Pancreatic Tissue from $\mathrm{Cd}-, \mathrm{Pb}$ - and $\mathrm{Cu}$ - Provoked Lipid Peroxidation Monitoring via MDA Content among Wistar Rats. In J. Campbell (ed) "Malondialdehyde (MDA): Structure, Biochemistry and Role in Disease" Nova Science Publishers, Inc.: Hauppauge NY 11788-3619, 2015, pp. 55-83.

2. N. Das, R. Vimala, P. Karthika, Indian journal of Biotechnology, 2008, 7(2), 159.

3. B. Volesky, in "Biotechnology and Bioengineering Symposium", 1986, pp. 1216 (John Wiley \& Sons: New York).

4. B. Volesky, "Biosorption of heavy metals", CRC press, Boca Raton, Florida, 1990.

5. J.L. Wang, "Immobilization techniques for biocatalysts and water pollution control", Science Press, Beijing, 2002.

6. P. Nowicki, M. Skrzypczak, R. Pietrzak, Chemical Engineering Journal, 2010, 162(2), 723.

7. C. Biriescu, V. Chiriac, H. Popovici, D. Vlascici, Annals of West University of Timisoara, 2012, 21(1), 7.

8. B. Dhir, R. Kumar, International Journal of Environmental Research, 2010, 4(3), 427.

9. H. Elifantz, E. Tel-Or, Water, air, and soil pollution, 2002, 141(1-4), 207.

10. M. Grubor, Archives of Biological Sciences, 2008, 60(2), 239. 
VLADIMIR D. DIMITRIJEVIĆ, MAJA N. STANKOVIĆ, DRAGAN M. ĐORĐEVIĆ, IVAN M. KRSTIĆ, MILICA G. NIKOLIĆ, ALEKSANDAR LJ. BOJIĆ, NENAD S. KRSTIĆ

11. Z. Mousavy, S. Seyedi, Journal of the Chilean Chemical Society, 2010, 55(3), 307.

12. H.Z. Mousavi, S, Seyedi, International Journal of Environmental Science \& Technology, 2011, 8(1), 195.

13. I. Oboh, E. Aluyor, T. Audu, Leonardo Journal of Sciences, 2009, 14, 58.

14. D. Kregiel, E. Pawlikowska, H. Antolak. Molecules, 2018, 23(7), 1664.

15. C. Malone, D. Koeppe, R.J. Miller, Plant Physiology, 1974, 53(3), 388.

16. A.S. Moffat, Science, 1995, 269(5222), 302.

17. J. Shaw, "Heavy metal tolerance in plants: evolutionary aspects", CRC press, Boca Raton, Florida, 1989.

18. C.D. Lingegowda, J.K. Kumar, A.D. Prasad, M. Zarei, S. Gopal, Romanian Journal of Biophysics, 2012, 22(3-4), 137.

19. M.N. Stanković, N.S. Krstić, I.J. Slipper, J.Z. Mitrović, M.D. Radović, D.V. Bojić, A. Lj. Bojić, Australian Journal of Chemistry, 2013, 66(2), 227.

20. M.A. Maobe, R.M. Nyarango, World Applied Sciences Journal, 2013, 21(8), 1128.

21. N.M. Salem, A.M. Farhan, A.M. Awwad, American Journal of Environmental Engineering, 2012, 2(5), 123.

22. M.K. Baseri, S. Baker, Romanian Journal of Biophysics, 2011, 21, 277.

23. Y. Mariswamy, W.E. Gnanaraj, J.M. Antonisamy, Asian Journal of Pharmaceutical and Clinical Research, 2012, 5(2), 4.

24. E.J. Baran, C.H. Rolleri, Brazilian Journal of Botany, 2010, 33(3), 519.

25. Z. Kariuki, J. Kiptoo, D. Onyancha, South African Journal of Chemical Engineering, 2017, 23, 62.

26. K.D. Kowanga, E. Gatebe, G.O. Mauti, E.M. Mauti, The Journal of Phyto Pharmacology, 2016, 5(2), 71.

27. J.-P. Simonin, Journal Chemical Engineering, 2016, 300, 254.

28. K. Steve, T. Erika, M. Reynold, T. Paul, "Activated carbon: A unit operations and processes of activated carbon". Environmental engineering, $2^{\text {nd }}$ ed. PWS Publishing Co. 1998.

29. C. Ng, J.N. Losso, W.E. Marshall, R.M. Rao, Bioresource technology, 2002, 85(2), 131.

30. M. Barbera, G. Gurnari, "Wastewater Treatment and Reuse in the Food Industry", Springer, 2017.

31. N. Velinov, S. Najdanović, M. Radović, J. Mitrović, M. Kostić, D. Bojić, A. Bojić, Cellulose Chemistry and Technology, 2019, 53(1-2), 175.

32. Y. Liu, Y-J. Liu, Separation and Purification Technology, 2008, 61(3), 229.

33. N.D. Hutson, R.T. Yang, Adsorption, 1997, 3(3), 189. 
THE PRELIMINARY ADSORPTION INVESTIGATION OF URTICA DIOICA L. BIOMASS MATERIAL AS A POTENTIAL BIOSORBENT FOR HEAVY METAL IONS

34. N. Ayawei, A.T. Ekubo, D. Wankasi, E.D. Dikio, Oriental Journal of Chemistry, 2015, 31(3), 38.

35. Y. Khambhaty, K. Mody, S. Basha, B. Jha, Chemical Engineering Journal, 2009, 145(3), 489.

36. E. Voudrias, K. Fytianos, E. Bozani, Global Nest International Journal, 2002, 4, 75.

37. S.V. Mohan, J. Karthikeyan, Environmental Pollution, 1997, 97(1), 183.

38. S. Goldberg, Equations and Models Describing Adsorption Processes. In M.A. Tabatabai, D.L. Sparks (eds) "Chemical Processes in Soils" SSSA Book Series 8, Soil Science Society of America: Madison, WI, 2005, pp. 489-517.

39. Y. Kim, C. Kim, I. Choi, S. Rengaraj, J. Yi, Environmental science \& technology, 2004, 38(3), 924.

40. M.J. Horsfall, A.I. Spiff, A. Abia, Bulletin of the Korean Chemical Society, 2004, 25(7), 969.

41. A. Günay, E. Arslankaya, I. Tosun, Journal of Hazardous Materials, 2007, 146(1), 362.

42. A. Dąbrowski, Advances in colloid and interface science, 2001, 93(1), 135.

43. A. Hammaini, F. Gonzalez, A. Ballester, M. Blázquez, J. Munoz, Minerals Engineering, 2003, 16(8), 723.

44. D.-L.D. Mitić, "Removal of heavy metals from water using biosorbent based on Lagenaria vulgaris“, PhD, 2012, University of Niš, Serbia, Niš, Serbia.

45. W-B. Lu, W-C. Kao, J-J. Shi, J-S. Chang, Journal of hazardous materials, 2008, 153(1), 372.

46. S.K. Papageorgiou, F. Katsaros, E. Kouvelos, N. Kanellopoulos. Journal of Hazardous Materials, 2009, 162(2), 1347.

47. Y.-R. Cao, Z. Liu, G-I. X-b. Jing, H Xu, Chemical Engineering Journal, 2010, 164(1), 183.

48. C. Mahamadi, T. Nharingo Cheng, Bioresource Technology, 2010, 101(3), 859. 
